\title{
PENGHADIRAN BALAI DAN REKREASI KAMPUNG NELAYAN CILINCING SEBAGAI TEMPAT KETIGA ATAS SOLUSI MASALAH SOSIAL
}

\author{
Ciputra Tri Sutomi ${ }^{11}$, Doddy Yuono ${ }^{2)}$ \\ 1)Program Studi S1 Arsitektur, Fakultas Teknik, Universitas Tarumanagara, imcitsu@gmail.com \\ 2)Program Studi S1 Arsitektur, Fakultas Teknik, Universitas Tarumanagara, doddy@ft.untar.ac.id
}

\begin{abstract}
Abstrak
Kota Jakarta Utara yang merupakan kota administrasi DKI Jakarta dengan seluruh bagian utaranya dibatasi oleh perairan Laut Jawa, mempunyai potensi ekonomi secara kemaritiman yang besar tentu tidak luput dari tujuan urbanisasi yang pesat. Kekayaan potensi ekonomi kelautan yang sebagian besar berupa pelabuhan, pergudangan, perikanan, dan pariwisata mengundang para migran untuk dengan cepat memenuhi daerah-daerah di Jakarta Utara. Urbanisasi yang tidak diimbangi dengan fasilitas pendukung permukiman menghasilkan daerah-daerah permukiman masyarakat yang kumuh dan tidak teratur. Fenomena ini juga yang terjadi di Kampung Nelayan Cilincing. Keadaan ini menyumbang peran dalam ketidakmampuan masyarakat dari himpitan kemiskinan dan konflik sosial. Maka dari itu, dihadirkan Balai dan Rekreasi Kampung Nelayan Cilincing sebagai sebuah tempat ketiga yang dapat mewadahi berbagai kegiatan masyarakat sekitar dengan tujuan membantu dalam menyelesaikan masalah ekonomi dan sosial di Kampung Nelayan Cilincing. Penyediaan tempat ketiga sebagai ruang publik ini dilakukan dengan metode analisis-sintesis sehingga permasalahan dan solusi yang dihasilkan sesuai dengan kebutuhan masyarakat lokal dengan harapan dapat meningkatkan citra kawasan dan kualitas hidup masyarakat melalui program-program rancangan yang melibatkan interaksi antara orang sekitar dan pengunjung dari luar agar tercipta suatu komunitas masyarakat yang lebih ideal.
\end{abstract}

Kata kunci: balai kampung; kemiskinan; konflik sosial; ruang publik

\begin{abstract}
North Jakarta is one of the administrative city from Special Capital Region of Jakarta with all its northern parts limited by the waters of the Java Sea, has great maritime economic potential which certainly does not escape the destination of rapid urbanization. The rich potential of the marine economy which is mostly in the form of ports, warehousing, fisheries, and tourism invites migrants to quickly fill the regions in North Jakarta. Urbanization that is not followed with settlement support facilities results in slums and unorganized areas of community settlements. This phenomenon also occurs in the Cilincing Fishermen Village. This situation contributes to the community's inability to cope with poverty and social conflict. Therefore, Cilincing Fisherman Village Hall and Recreation is presented as a third place that can accommodate various activities of the surrounding community with the aim of helping in solving economic and social problems in the Cilincing Fisherman Village. Provision of the third place as a public space is carried out by the analysis-synthesis method so that the resulting problems and solutions are suitable with the needs of the local community in the hope that it can improve the image of the region and the quality of life of the community through design programs that involve interaction between the local people and outside visitors. a more ideal community is created.
\end{abstract}

Keywords: poverty; public space; social conflict; village hall 


\section{PENDAHULUAN}

Latar Belakang

Kota DKI Jakarta merupakan salah satu kota daerah administrasi khusus ibukota dimana terpusatnya segala aspek kehidupan masyarakat Indonesia, dari pemerintahan, pembangunan, ekonomi, budaya, sampai hiburan. Pemusatan ini menjadi daya tarik yang kuat bagi pendudukpenduduk provinsi lain untuk bermigrasi ke Jakarta dengan alasan memperbaiki peruntungan hidup mereka. Dengan persepsi bahwa Kota Jakarta mempunyai kesempatan yang lebih banyak untuk memperbaiki keadaan hidup, penduduk-penduduk dari provinsi lain memutuskan untuk datang dan bekerja di Jakarta, sehingga menyebabkan pertumbuhan penduduk yang besar. Laju urbanisasi yang pesat seperti ini (hingga $4 \%$ atau sekitar 222.738 orang per tahun) memunculkan kebutuhan akan tempat tinggal dan lapangan pekerjaan yang belum mampu difasilitasi oleh Pemerintah Provinsi DKI Jakarta. Oleh karena ketidakmampuan pemerintah daerah memfasilitasi hal tersebut, timbul masalah baru yaitu kepadatan penduduk yang tinggi (sekitar $14.337 \mathrm{jiwa} / \mathrm{km2}$ ) karena urbanisasi yang terpusat ini. Kepadatan penduduk yang tidak terkontrol jelas memberikan dampak negatif pada kehidupan perkotaan masyarakat Jakarta, mulai dari masalah kebersihan dan kesehatan, semakin tingginya tingkat kriminal dan rendahnya tingkat pendidikan karena tingkat kemiskinan yang juga tinggi, sampai dampak buruk psikologis (stress dan perilaku egosentris) yang diakibatkan oleh kemacetan dan tuntutan hidup.

Kota Administrasi Jakarta Utara yang seluruh wilayah bagian utara dibatasi oleh perairan Laut Jawa mempunyai potensi ekonomi secara kemaritiman yang besar tentu tidak luput dari tujuan urbanisasi yang pesat ini. Kekayaan potensi ekonomi kelautan yang sebagian besar berupa pelabuhan, pergudangan, perikanan, dan pariwisata mengundang para migran untuk dengan cepat memenuhi daerah-daerah di Jakarta Utara. Seperti contohnya kampung-kampung nelayan yang ada di pesisir pantai Jakarta Utara. Kondisi fisik kawasan kampung nelayan tersebut relatif sama, yaitu pemukiman nelayan yang padat dan kumuh dengan utilitas pendukung pemukiman yang tidak mumpuni. Keadaan ini secara tidak langsung menyumbang peran dalam ketidakmampuan masyarakat untuk lepas dari himpitan kemiskinan dan himpitan kemiskinan yang sudah menahun ini menyebabkan perilaku egosentris (individualisme) di masyarakat, selain kondisi masyarakat yang multi etnis yang juga berpotensi sebagai penyebabnya. Individualisme di masyarakat merupakan bibit awal terjadinya perpecahan (disintegrasi) di dalam tubuh masyarakat. Maka dari itu dibutuhkan intervensi dari berbagai pihak dan disiplin ilmu, termasuk arsitektur agar solusi yang dihasilkan dapat berkesinambungan. Peran bidang arsitektur dapat berupa penciptaan ruang publik bagi masyarakat yang diharapkan dapat mengkatalis terjadinya interaksi sosial yang minim, atau bahkan nihil konflik karena interaksi sosial itu sendiri dapat membawa perubahan pada hampir seluruh kondisi masyarakat menjadi lebih baik.

\section{Rumusan Permasalahan}

Berdasarkan latar belakang, rumusan masalah yang didapat antara lain:

a. Apa yang menjadi permasalahan utama kawasan sehingga membutuhkan sebuah third place

b. sebagai solusinya?

c. Bagaimana proyek dapat menjadi dan memenuhi fungsi third place bagi masyarakat sekitar?

\section{Tujuan}

Dalam menjawab permasalahan diatas, proyek dirancang dengan tujuan untuk merencanakan program-program arsitektur yang dapat memenuhi kebutuhan akan ruang ketiga dan memfasilitasi interaksi sosial, serta memperbaiki aspek-aspek kehidupan yang memburuk akibat konflik sosial di masyarakat Kampung Nelayan Cilincing. 


\section{KAJIAN LITERATUR Kampung Nelayan}

Dalam Kamus Besar Bahasa Indonesia, kata "kampung" didefinisikan sebagai kelompok rumah yang merupakan bagian kota yang biasanya dihuni orang berpenghasilan rendah. Sedangkan kata "nelayan", merupakan orang yang mata pencaharian utamanya adalah menangkap ikan di laut. Maka, "kampung nelayan" dapat diartikan sebagai kelompok rumah yang merupakan bagian kota yang dihuni oleh orang-orang yang mata pencaharian utamanya menangkap ikan di laut.

\section{Third Place: Open Architecture}

Dalam lingkup perilaku sosial, tempat ketiga (Third Place) adalah tempat yang netral dan informal yang menjadi ruang untuk berinteraksi, berekspresi, dan bertukar pikiran yang dapat digunakan oleh siapa saja. Tempat ini dapat digunakan untuk aktivitas apapun dan terletak diantara First Place yang merupakan rumah dan Second Place yang menjadi tempat bekerja. Menurut Ray Oldenburg dalam bukunya yang berjudul The Great Good Place (1997), third place memiliki karakteristik sebagai berikut :

a. On neutral ground. Third place harus menjadi tempat yang netral bagi semua kalangan. Tidak ada keberpihakan terhadap suatu kelompok, sehingga tercipta suatu komunitas yang beraneka ragam.

b. As leveler. Di dalam third place, orang-orang dapat berkumpul tanpa ada suatu tujuan tertentu dan tidak memandang tingkatan sosial lebih tinggi atau rendah (sejajar).

c. Conversation is the main activity. Terdapat sebuah aturan tak tertulis di dalam third place yang seolah mengatur bagaimana etika berbicara satu sama lain. Orang diminta untuk memperhatikan saat orang lain berbicara, tetap diam saat membagi waktu, berbicara sopan dengan membiarkan orang lain mendengar, dan ucapkan apa yang dipikirkan dengan tetap berhati-hati dalam menyampaikannya.

d. Third places are accessible. Third place adalah tempat yang mudah dicapai. Tidak ada rasa terkekang, terbatas, dan terkungkung.

e. The regulars. Setiap orang di third place pernah menjadi pendatang baru. Rasa penerimaan terhadap orang yang baru datang inilah yang menjadi faktor penting bagi keberlangsungan suatu third place itu sendiri.

f. A low profile. Citra sederhana yang dimunculkan sebuah third place menciptakan kenyamanan dan rasa kedekatan, tidak menekan, dan mengintimidasi.

g. The mood is playful. Selain citra sederhana, sebuah perasaan riang juga dimunculkan oleh third place agar orang yang datang merasa diterima dan menghilangkan rasa khawatir akan keterasingan.

h. A home away from home. Walaupun secara jarak fisik sebuah third place bisa jadi "jauh" dari rumah, perasaan yang ditimbulkan secara umum sama seperti ketika berada dirumah.

\section{Interaksi Sosial}

Manusia terlahir sebagai makhluk sosial, kenyataan tersebut menyebabkan manusia tidak dapat hidup normal tanpa kehadiran manusia yang lain. Hubungan tersebut dikategorikan sebagai interaksi sosial. Menurut Kimball Young (1959) pengertian interaksi sosial adalah hubungan yang terjadi antara manusia dengan manusia yang lain, baik secara individu maupun dengan kelompok. Proses interaksi sosial dalam masyarakat memiliki ciri sebagai berikut :

a. Adanya dua orang pelaku atau lebih.

b. Adanya hubungan timbal balik antar pelaku.

c. Diawali dengan adanya kontak sosial, baik secara langsung atau tidak langsung.

d. Mempunyai maksud dan tujuan yang jelas.

Menurut Soerjono Seikanto (2010), bentuk interaksi sosial dibedakan menjadi dua bentuk, yaitu asosiatif dan disosiatif dengan penjabaran sebagai berikut: 


\section{Asosiatif}

Interaksi sosial bersifat asosiatif akan mengarah pada bentuk penyatuan. Interaksi sosial ini terdiri atas beberapa hal berikut:

a. Kerja sama (cooperation)

Kerjasama terbentuk karena masyarakat menyadari bahwa mereka mempunyai kepentingan- kepentingan yang sama sehingga sepakat untuk bekerjasama dalam mencapai tujuan bersama. Berdasarkan pelaksanaannya terdapat empat bentuk kerjasama, yaitu bargaining (tawar-menawar), cooptation (kooptasi), koalisi dan joint-venture (usaha patungan).

b. Akomodasi

Akomodasi merupakan suatu proses penyesuaian antara individu dengan individu, individu dengan kelompok, atau kelompok dengan kelompok guna mengurangi, mencegah, atau mengatasi ketegangan dan kekacauan. Proses akomodasi dibedakan menjadi bebrapa bentuk antara lain Coercion yaitu suatu bentuk akomodasi yang prosesnya dilaksanakan karena adanya paksaan; Kompromi yaitu suatu bentuk akomodasi dimana pihak-pihak yang terlibat masing- masing mengurangi tuntutannya agar tercapai suatu penyelesaian; Mediasi yaitu cara menyelesaikan konflik dengan jalan meminta bantuan pihak ketiga yang netral; Arbitrase yaitu cara mencapai kompromi dengan cara meminta bantuan pihak ketiga yang dipilih oleh kedua belah pihak atau oleh badan yang kedudukannya lebih dari pihak-pihak yang bertikai; Adjudication (peradilan) yaitu suatu bentuk penyelesaian konflik melalui pengadilan; Stalemate yaitu suatu keadaan dimana pihak-pihak yang bertentangan memiliki kekuatan yang seimbang dan berhenti melakukan pertentangan pada suatu titik karena kedua belah pihak sudah tidak mungkin lagi maju atau mundur; Toleransi yaitu, suatu bentuk akomodasi tanpa adanya persetujuan formal; Consiliation yaitu, usaha untuk mempertemukan keinginan-keinginan pihak- pihak yang berselisih bagi tercapainya suatu persetujuan Bersama

c. Asimilasi

Proses asimilasi menunjuk pada proses yang ditandai adanya usaha mengurangi perbedaan yang terdapat diantara beberapa orang atau kelompok dalam masyarakat serta usaha menyamakan sikap, mental, dan tindakan demi tercapainya tujuan bersama. Asimilasi timbul bila ada kelompok masyarakat dengan latar belakang kebudayaan yang berbeda, saling bergaul secara intensif dalam jangka waktu lama, sehingga lambat laun kebudayaan asli mereka akan berubah sifat dan wujudnya membentuk kebudayaan baru sebagai kebudayaancampuran.

d. Akulturasi

Proses sosial yang timbul, apabila suatu kelompok masyarakat manusia dengan suatu kebudayaan tertentu dihadapkan dengan unsur - unsur dari suatu kebudayaan asing sedemikian rupa sehingga lambat laun unsur - unsur kebudayaan asing itu diterima dan diolah ke dalam kebudayaan sendiri, tanpa menyebabkan hilangnya kepribadian dari kebudayaan itu sendiri.

\section{Disosiatif}

Interaksi sosial ini mengarah pada bentuk pemisahan dan terbagi dalam tiga bentuk sebagai berikut:

\section{a. Persaingan/kompetisi}

Adalah suatu perjuangan yang dilakukan perorangan atau kelompok sosial tertentu, agar memperoleh kemenangan atau hasil secara kompetitif, tanpa menimbulkan ancaman atau benturan fisik di pihak lawannya. 
b. Kontravensi

Adalah bentuk proses sosial yang berada di antara persaingan dan pertentangan atau konflik. Wujud kontravensi antara lain sikap tidak senang, baik secara tersembunyi maupun secara terang - terangan seperti perbuatan menghalangi, menghasut, memfitnah, berkhianat, provokasi, dan intimidasi yang ditunjukan terhadap perorangan atau kelompok atau terhadap unsur - unsur kebudayaan golongan tertentu. Sikap tersebut dapat berubah menjadi kebencian akan tetapi tidak sampai menjadi pertentangan atau konflik.

c. Konflik

Adalah proses sosial antar perorangan atau kelompok masyarakat tertentu, akibat adanya perbedaan paham dan kepentingan yang sangat mendasar, sehingga menimbulkan adanya semacam gap atau jurang pemisah yang mengganjal interaksi sosial di antara mereka yang bertikai tersebut.

Masyarakat Indonesia terdiri dari berbagai budaya, secara logis akan mengalami berbagai permasalahan sosial. Berikut adalah beberapa bentuk permasalahan yang dapat memicu konflik dalam interaksi sosial:

a. Etnosentrisme

Secara formal didefinisikan sebagai pandangan bahwa kelompok sendiri adalah pusat segalanya dan kelompok lain akan selalu dibandingkan dan dinilai sesuai dengan standar kelompok sendiri.

b. Misunderstanding of Culture Values

Pluralitas dan keragaman antar suku, bangsa, agama dan budaya dalam pemahaman kerangka kesatuan manusia menciptakan sikap-sikap moderat bagi setiap individu, itu pada satu sisi, namun pada sisi lain akan memunculkan gesekan-gesekan yang pada akhirnya melahirkan sikap egosentrisme yang berimplikasi pada penolakan terhadap budaya lain dengan klaim budaya sendiri sebagai standar, dengan memaksakan nilai-nilai budayanya sebagai acuan terhadap budaya lain.

c. Stereotip

Stereotip merupakan keyakinan yang terlalu menggenalisir, disederhanakan, atau dilebih lebihkan terhadap kelompok etnis tertentu. Stereotip adalah mengidentifikasi individu pada basis anggota kelompok tertentu, dan menilai diri individu tersebut.

d. Prasangka

Penghambat komunikasi antarbudaya lainnya adalah prasangka. Prasangka akan selalu merujuk pada pendapat atau penilaian seseorang sebelum kenal dengan orang tersebut. Prasangka merupakan resistensi atau penolakan terhdap semua bukti yang akan menggesernya. Kita cenderung menjadi emosional ketika prasangka terancam oleh hal-hal yang bersifat kontradiktif.

\section{Open Space: Utopia is not Just a Building}

Dapatkah sebuah ruang terbuka menjadi inti dari sebuah masyarakat? Jawabannya adalah ya, bahkan hal ini haruslah menjadi tujuan awalnya. Salah satu contoh yang baik adalah Minamihara Resort yang terkenal sebagai pusat turis saat musim panas di Karuizawa, prefektur Nagano, Jepang. Dua orang lokal yang kaya dan terpandang sebagai pemberi proyek, mengajukan dua syarat utama kepada pengembang yang ditunjuk. Pertama, situs villa tidak boleh ada gerbang ataupun dipagari dan syarat kedua, harus ada sebuah lapangan terbuka di tengah - tengah dengan fasilitas les privat bagi anak - anak. Pengurus - pengurus resort merupakan keluarga keluarga lokal dan diberi tempat tinggal di dalam lingkungan resort. Awalnya pengurus resort hanya terdiri dari beberapa keluarga. Seiring dengan pengembangan - pengembangan yang dilakukan, resort ini sekarang mempekerjakan lebih dari seribu anggota pengurus. Yang membedakan Minamihara Resort dengan resort lain di Jepang adalah walaupun sekarang sudah banyak keluarga - keluarga pengurus resort yang pindah untuk menetap di kota - kota besar 
lain, mereka tetap diijinkan untuk kembali ke Resort Minamihara saat musim panas, mereka menyebutnya "perkampungan musim panas" (summer settlement). Anggota pengurus yang masih muda juga diketahui menikahi satu sama lain dan berkeluarga di dalam lingkungan resort. Sebuah bungalo dan lapangan tenis dibangun di lapangan terbukanya, serta beragam acara seperti perlombaan olah raga dan pesta kembang api diadakan di lapangan terbuka tersebut.

Dalam sebuah ruang terbuka sebagai "laboratorium" (tempat pembelajaran dan eksperimen), tidak hanya perilaku manusia saja yang bisa dipelajari. Ruang terbuka juga menjadi sebuah tempat yang bagus untuk memahami beragam perilaku alam seperti contohnya, udara yang melewati area pepohonan terbukti menjadi lebih sejuk dan juga pembelajaran mengenai perlakuan terhadap air. Relasi antara perilaku manusia dengan objek arsitektur dalam ruang terbuka juga menarik. Di halaman depan kampus International College for Postgraduate Buddhist Studies, terdapat instalasi sederhana berupa lingkaran kosentris yang juga merepresentasikan "tujuh lingkaran" dalam simbol agama Buddha. Saat diobservasi, anak anak kecil senang bermain di area instalasi tersebut. Karakteristik terbuka dengan tanah yang dibuat miring menjadi ideal sebagai sarana bermain anak karena anak kecil pada dasarnya senang dengan lingkaran dan tanah yang dibuat miring tersebut digunakan anak kecil untuk berlompat - lompat naik turun.

Secara umum, sebuah ruang terbuka mempunyai kualitas sentripetal dan kualitas sentrifugal yang bekerja secara bersamaan. Batas - batas yang dihasilkan dari sebuah ruang terbuka secara tidak langsung mempengaruhi perkembangan lingkungan sekitarnya (kualitas sentrifugal). Dalam sebuah skenario lain, di antara dua bangunan tinggi terdapat ruang negatif hasil peletakan bangunan - bangunan utama yang bersifat sempit memanjang. Sebuah ruang terbuka yang dirancang di ruang negatif ini, dalam bentuk jalur pejalan kaki yang lebar dengan fasilitas fasilitas tertentu misalnya, menjadikan ruang terbuka ini sebuah place of interest (kualitas sentripetal). Konfigurasi ruang seperti ini juga menjadikan bangunan tinggi dan bangunan rendah berdampingan tanpa mengganggu satu sama lain.

\section{METODE}

\section{Metode Penelitian dan Analisis}

Dalam penyelesaian proyek, diperlukan tahapan-tahapan penelitian untuk merancang sebuah desain yang tepat guna dan bermanfaat bagi penggunanya. Maka dari itu dilakukan metode penelitian sebagai berikut :

a. Pengumpulan Data

Pengumpulan data berupa studi literatur dilakukan dengan perolehan data berdasarkan teori, kajian, serta sumber-sumber informasi lainnya. Dilakukan juga studi preseden sebagai cara untuk memahami proyek-proyek lain yang serupa sebagai bahan pembanding. Studi preseden yang diambil adalah RPTRA Kalijodo, Plaza Benteng Kuto Besak, dan SSpace.

b. Survey Lapangan

Survey dilakukan untuk mendapatkan data tapak yang lebih akurat dan juga untuk mengetahui keadaan tapak secara nyata. Data survey didapatkan dengan pengambilan dokumentasi yang berupa video dan foto, serta wawancara singkat dengan masyarakat sekitar. Lokasi survey adalah Kampung Nelayan Cilincing dengan rentang waktu pengamatan dari pagi sampai sore hari.

Data-data yang telah didapatkan dari penelitian kemudian diolah menjadi poin-poin yang dipakai sebagai dasar perancangan dengan metode analisis-sintesis. Metode analisis-sintesis ini merupakan metode yang menguraikan permasalahan menjadi bagian-bagian sendiri agar memunculkan solusi, lalu digabungkan dan disusun menjadi sebuah sistem atau konsep perancangan. 


\section{Metode Perancangan}

Metode perancangan yang digunakan sebagai dasar dalam penyelesaiaan proyek adalah metode perancangan secara disprogramming yang merupakan ide konsep perancangan milik Bernard Tschumi. Disprogramming adalah metode yang menyatukan dua atau beberapa program sedemikian rupa sehingga konfigurasi program pertama mengkontaminasi konfigurasi program kedua dan lainnya. Dari analisis isu yang ada di kawasan, akan ditemukan kebutuhankebutuhan masyarakat sekitar yang nanti akan menghasilkan program-program. Bentuk dari program-program yang dihasilkan akan "menganggu" satu sama lain, sesuai dengan konsep disprogramming.

\section{DISKUSI DAN HASIL Profil Tapak}

Tapak berada di Kampung Nelayan Cilincing, Jakarta Utara. Kampung Nelayan Cilincing merupakan salah satu titik urbanisasi yang tidak terkontrol, sehingga menjadi sebuah kawasan pemukiman nelayan yang kumuh dan identik dengan kemiskinan. Bangunan-bangunan rumah tersusun secara tidak teratur dan terlihat tumpang tindih tanpa dilengkapi dengan utilitas pendukung permukiman yang baik.

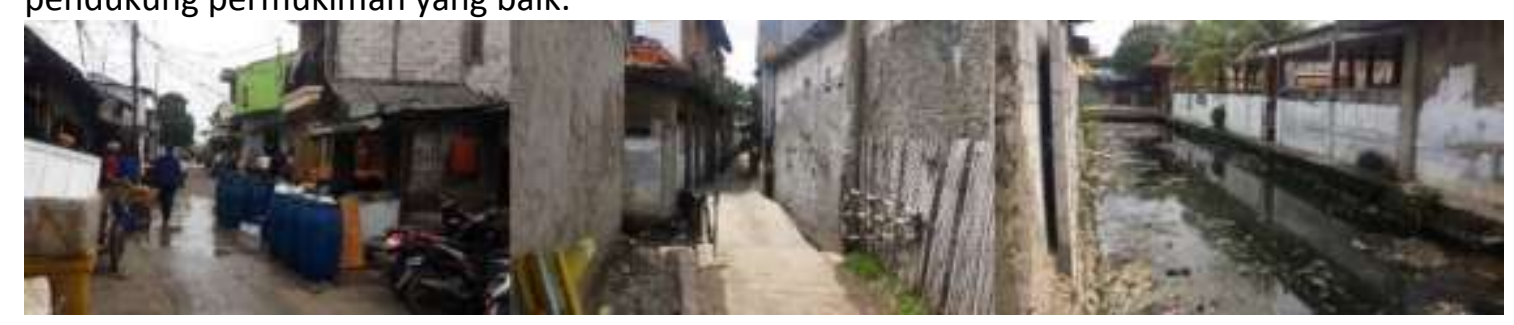

Gambar 1. Foto situasi sekitar tapak

Sumber: Dokumentasi Penulis, 2020

Secara lebih jelas, tapak berada di Jalan Cilincing Krematorium, Kelurahan Cilincing Utara dengan spesifikasi yaitu
a. Luasan tapak : $4.430 \mathrm{~m}^{2}$
b. KDB : $40 \%\left(1.772 \mathrm{~m}^{2}\right)$
c. KLB : $1.20\left(5.316 \mathrm{~m}^{2}\right)$
d. $K B: 3$
e. $\mathrm{KDH}: 30 \%\left(1.550 \mathrm{~m}^{2}\right)$
f. Zona tapak : Zona Prasarana Pelayanan Umum (020.S.6)
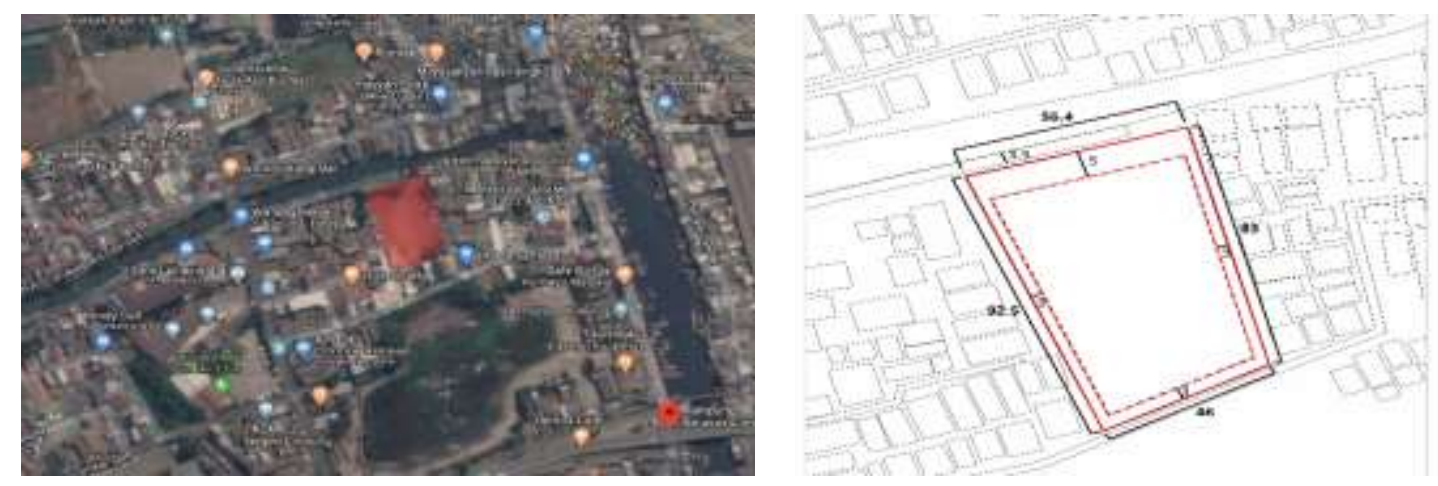

Gambar 2. Lokasi dan ukuran tapak

Sumber: Penulis, 2020 


\section{Program}

Program secara umum disusun berdasarkan analisis kebutuhan yang didapatkan dari solusi atas isu-isu yang berkembang di kawasan. Strategi yang digunakan dalam penyelesaian isu adalah adaptasi terhadap situasi yang muncul akibat isu dan konsolidasi untuk masalah sosialnya.

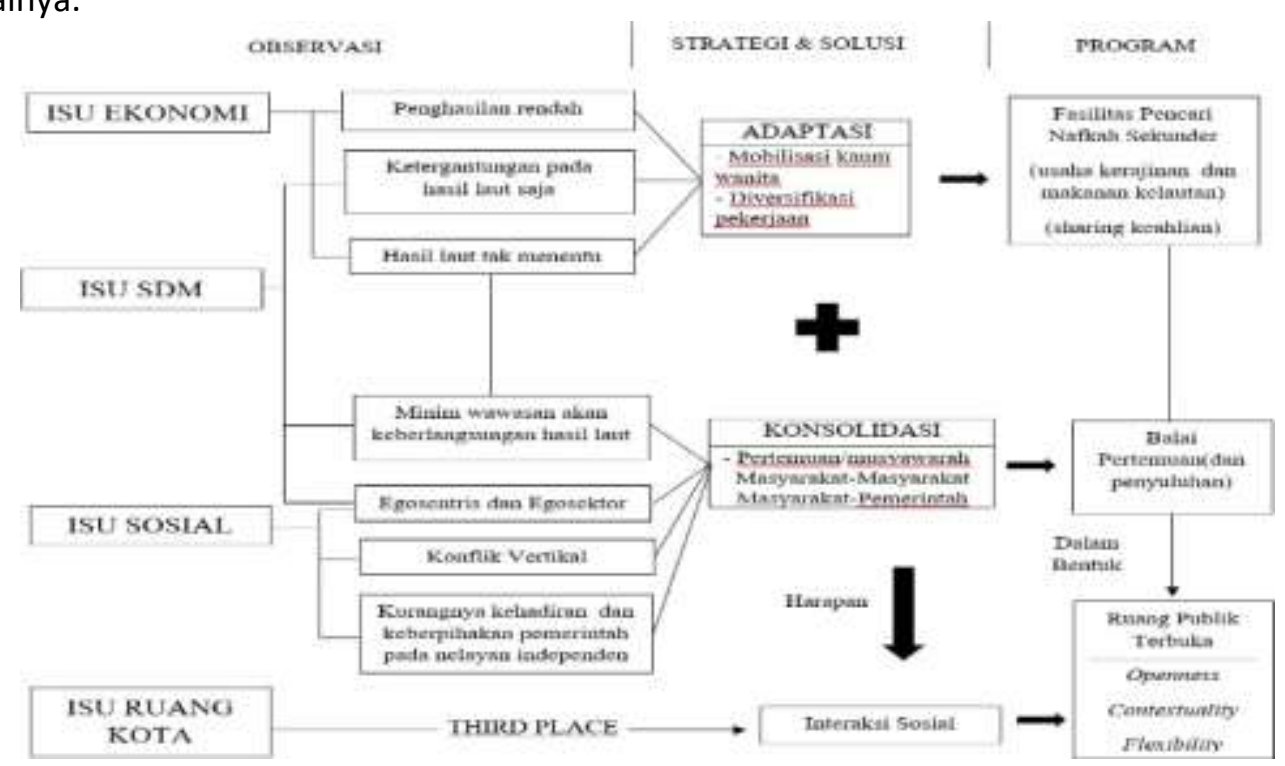

Gambar 3. Diagram penyusunan program

Sumber: Penulis, 2020

Dari hasil analisis di atas, penjabaran program yang lebih jelas adalah sebagai berikut :

a. Balai Pertemuan

Akibat adanya potensi perpecahan dalam masyarakat akibat konflik sosial, dibutuhkan interaksi sosial yang secara umum berbentuk dialog baik yang sifatnya formal, maupun tidak formal. Penciptaan ruang-ruang untuk berdialog dalam bentuk balai pertemuan dibutuhkan dalam perancangan untuk memfasilitasi konsolidasi antara masyarakat dengan masyarakat dan masyarakat dengan pemerintah.

b. Fasilitas Pencari Nafkah Sekunder

Rendahnya perekonomian masyarakat nelayan di Kelurahan Cilincing, mengharuskan mereka untuk beradaptasi dengan cara mencari sumber penghasilan lain dan menggerakkan kaum perempuan sebagai pelaku ekonomi. Program fasilitas pencari nafkah sekunder ini berupa retail makanan, retail kerajinan, dan café.

c. Ruang Publik

Selain berdialog, interaksi sosial lain bisa terjadi di dalam bangunan yang dirancang. Para nelayan dapat memperbaiki jala sambil berdiskusi saat sedang tidak melaut, pengunjung dapat berkumpul, dan anak-anak dapat bermain sambil belajar di dalam bangunan. Maka dari itu dibutuhkan ruang-ruang seperti shelter anak dan shelter umum untuk memfasilitasi kebutuhan tersebut.

d. Ruang Publik Terbuka

Kurangnya ruang publik terbuka di kawasan sekitar, membuat masyarakat tidak punya pilihan lain selain di bangunan rancangan. Pengadaan taman, taman bermain anak, dan ruang-ruang hijau terbuka lain seperti kolam pemancingan dibutuhkan untuk memenuhi kebutuhan ini. 


\section{Zoning Bangunan}

Secara garis besar, bangunan dibagi menjadi 2 bagian yaitu bagian yang dimaksimalkan bagi pengunjung dari luar yang berada di sebelah barat dan bagian yang dimaksimalkan bagi pengunjung lokal yang berada di sebelah timur. Bangunan bagian barat berisikan ruang-ruang untuk informasi dan komersil, sedangkan bagian timur merupakan ruang-ruang pertemuan (balai) dan shelter umum \& anak.

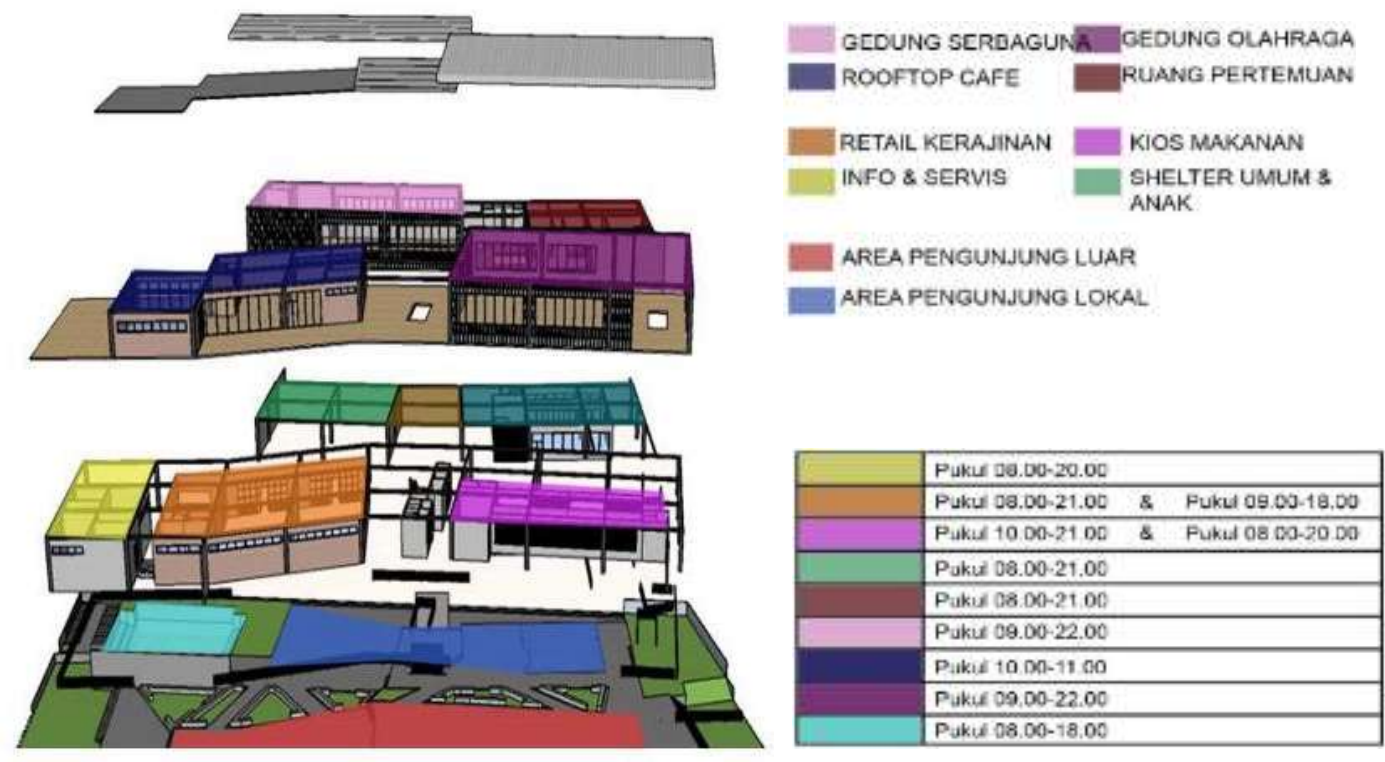

Gambar 4. Gambar pembagian ruang

Sumber: Penulis, 2020

Di lantai dasar terdapat 2 jenis ruang, yaitu ruang terbuka hijau dan ruang dalam bangunan (indoor). Ruang terbuka hijau terdiri dari taman dan kolam pemancingan di bagian utara, taman samping di bagian barat, area santai nelayan di bagian timur, dan taman bermain anakanak di bagian selatan. Sedangkan untuk dalam bangunan, terdapat ruang informasi, servis, retail kerajinan, dan retail makanan di bagian barat dan shelter anak, shelter umum, dan ruang berkumpul informal di bagian timurnya. Lantai 2 berisikan rooftop café dan lapangan bulu tangkis di bagian barat dan ruang serbaguna $\&$ ruang pertemuan formal di bagian timurnya. Karena diapit oleh pemukiman padat di sebelah timur dan barat tapak, terdapat area buffer yang digunakan untuk tempat beraktivitas sebagai pemisah antara bangunan dan area pemukiman. Area buffer tersebut diwujudkan dalam bentuk taman samping di bagian barat dan area santai nelayan di bagian timur. Fungsi dari area buffer ini sebagai ruang transisi agar bangunan tidak terkesan memunggungi area pemukiman.

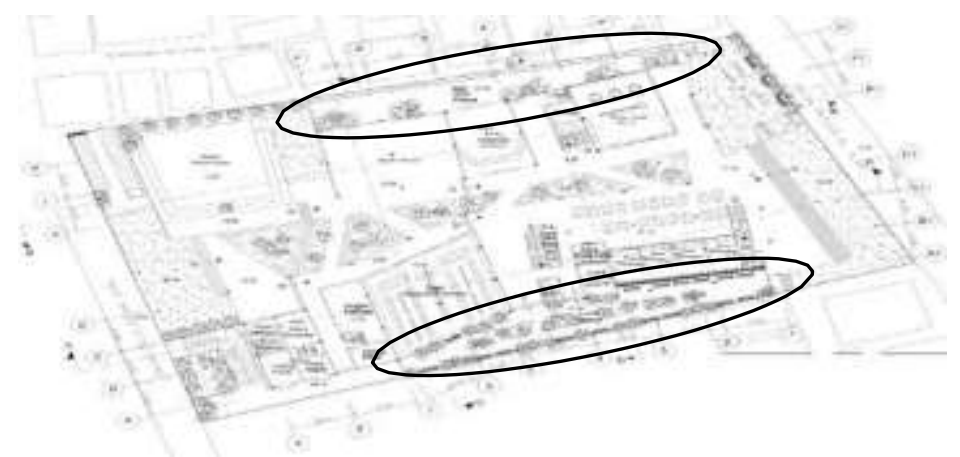

Gambar 5. Denah lantai dasar Sumber: Penulis, 2020 


\section{Bentuk Rancangan}

Berdasarkan program dan analisis sekitar, massa bangunan terbentuk dari hasil adaptasinya dengan mengikuti parameter-parameter yang secara tidak langsung hadir sebagai hasil dari analisis dan program tersebut. Berikut tahapan-tahapan pengembangan massa yang dimaksud:

a. Massa awal berbentuk flat dan masih menyerupai wujud tapak yang diberikan dimensi.

b. Lalu bagian tengah massa dibelah sehingga menjadi dua bagian yang juga memisahkan sifat kedua bangunan. Pemisahan ini juga memungkinkan wind tunnel yang memperkuat aspek kenyamanan.

c. Diantara kedua massa yang pipih ini, dibelah lagi agar dua sisi di sebelah barat dan timur tidak menjadi pambatas antara tapak dengan lingkungan sekitar.

d. Massa di lantai kedua ditambahkan dan berfungsi sebagai penyambung massa di lantai dasar yang terpisah agar tetap terlihat sebagai satu kesatuan.

e. Lalu diberikan permainan ketinggian di massa lantai kedua agar senada dengan kontur ketinggian bangunan sekitar yang juga beraneka ragam.

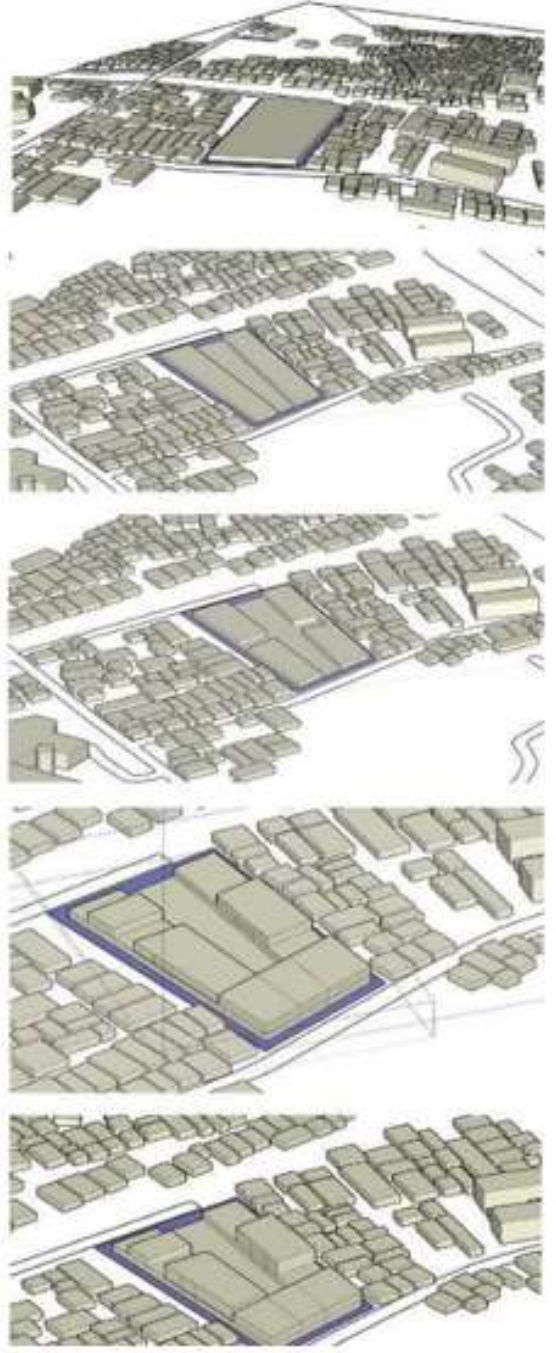

Gambar 6. Pengembangan massa Sumber: Penulis, 2020

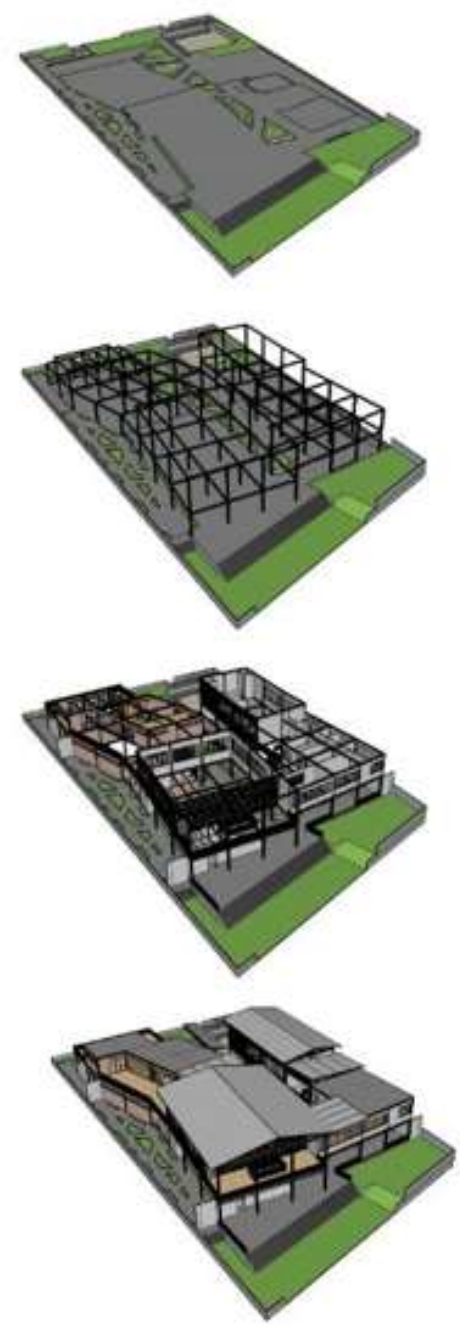

Gambar 7. Komponen bangunan Sumber: Penulis, 2020 


\section{Hasil Rancangan}

Desain bangunan secara keseluruhan dibuat tidak terlalu masif sehingga pencahayaan alami dapat dimanfaatkan dengan efektif agar penggunaan pencahayaan buatan tidak dibutuhkan banyak saat masih ada matahari. Wind tunnel yang tercipta dari proses massa juga membantu dalam pemanfaatan pengudaraan alami dengan maksimal, karena tapak berada di dekat pantai. Pohon dan rumput di dalam kompleks bangunan selain sebagai unsur peneduh, juga berfungsi sebagai tempat berinteraksi yang menarik.

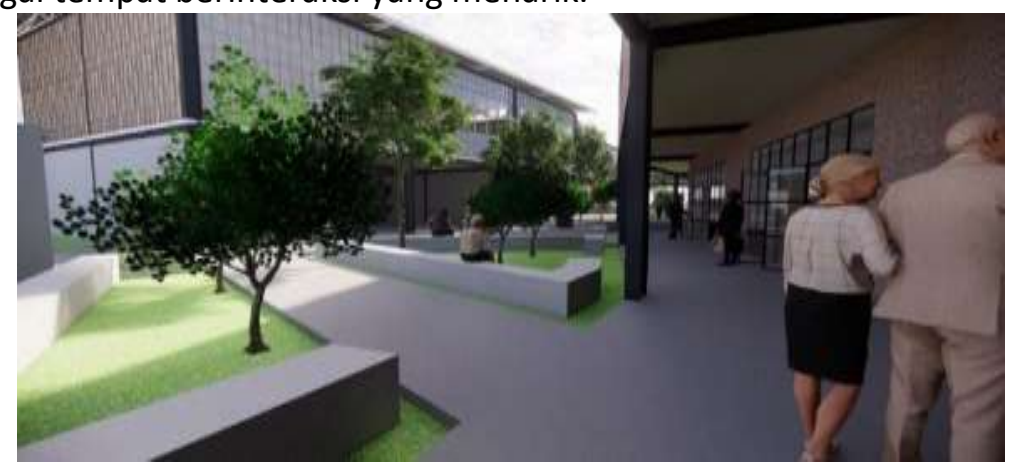

Gambar 8. Gambar bagian tengah bangunan Sumber: Penulis, 2020

Bentuk bangunan terlihat seolah tidak teratur sesuai dengan konsep yang digunakan dan terdapat perbedaan ketinggian antara atap-atapnya agar senada dengan bangunan-bangunan sekitar. Usaha ini dilakukan agar masyarakat sekitar tidak merasa asing dan merasa diterima dengan bangunan yang dirancang karena penampakan bangunan secara umum tidak terlalu berbeda dengan bangunan- bangunan yang ada di sekelilingnya.

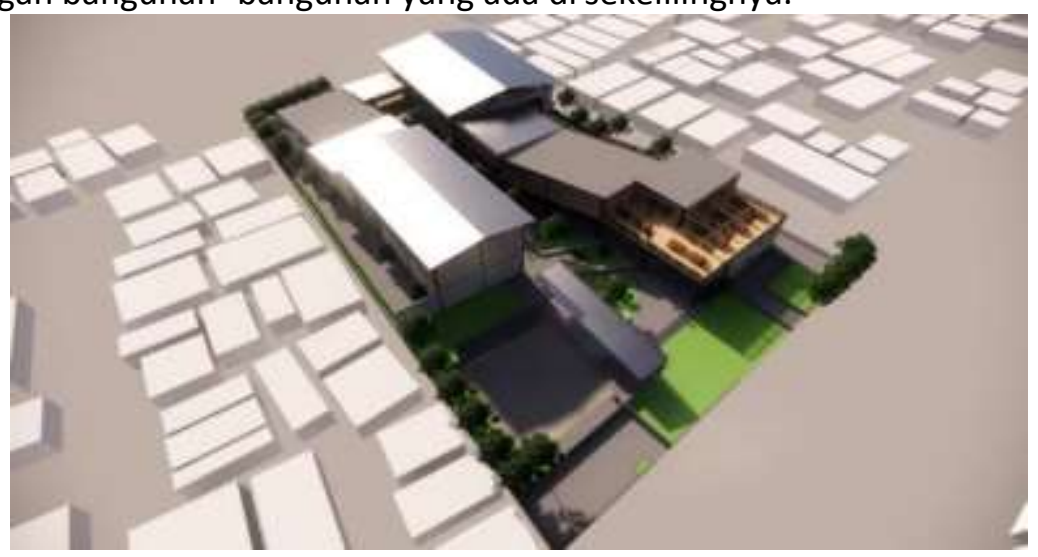

Gambar 9. Gambar perspektif eksterior bird eye view Sumber: Penulis, 2020

Interior bangunan memberikan kesan simple dan lokal agar masyarakat sekitar memiliki rasa kepemilikian, tetapi tetap nyaman juga bagi pengunjung luar. Anak - anak diberikan area bermain dan belajar, bagi para nelayan ada tempat bersantai dan berkumpul, bagi istri nelayan dan nelayan itu sendiri diberikan tempat usaha sebagai jawaban atas tempat ketiga yang terbuka bagi semua golongan dan usaha diversifikasi pekerjaan \& mobilisasi kaum perempuan yang nyata. 


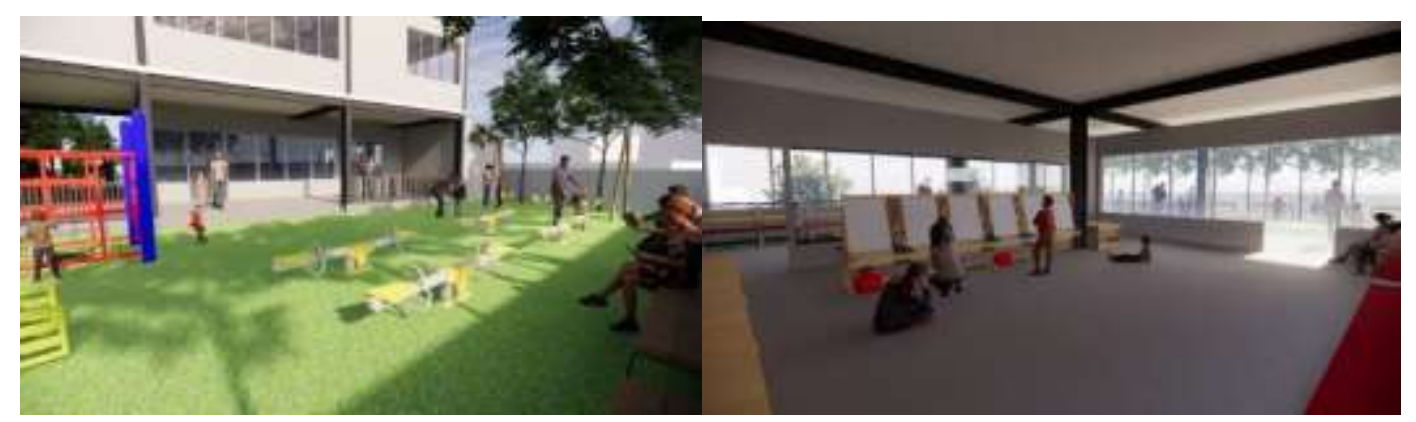

Gambar 10. Gambar taman bermain dan shelter anak Sumber: Penulis, 2020

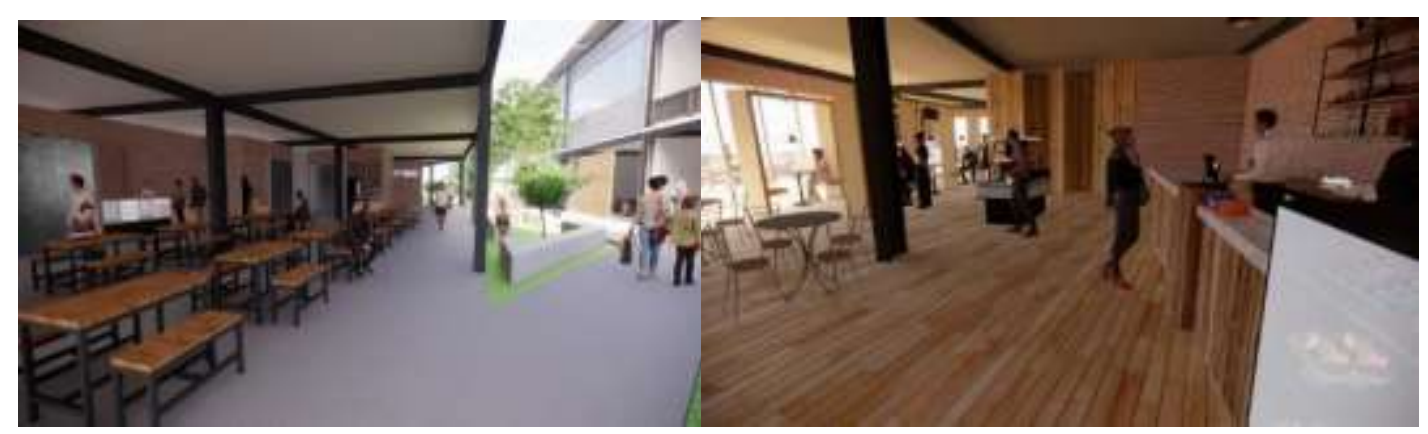

Gambar 11. Gambar retail makanan dan café Sumber: Penulis, 2020

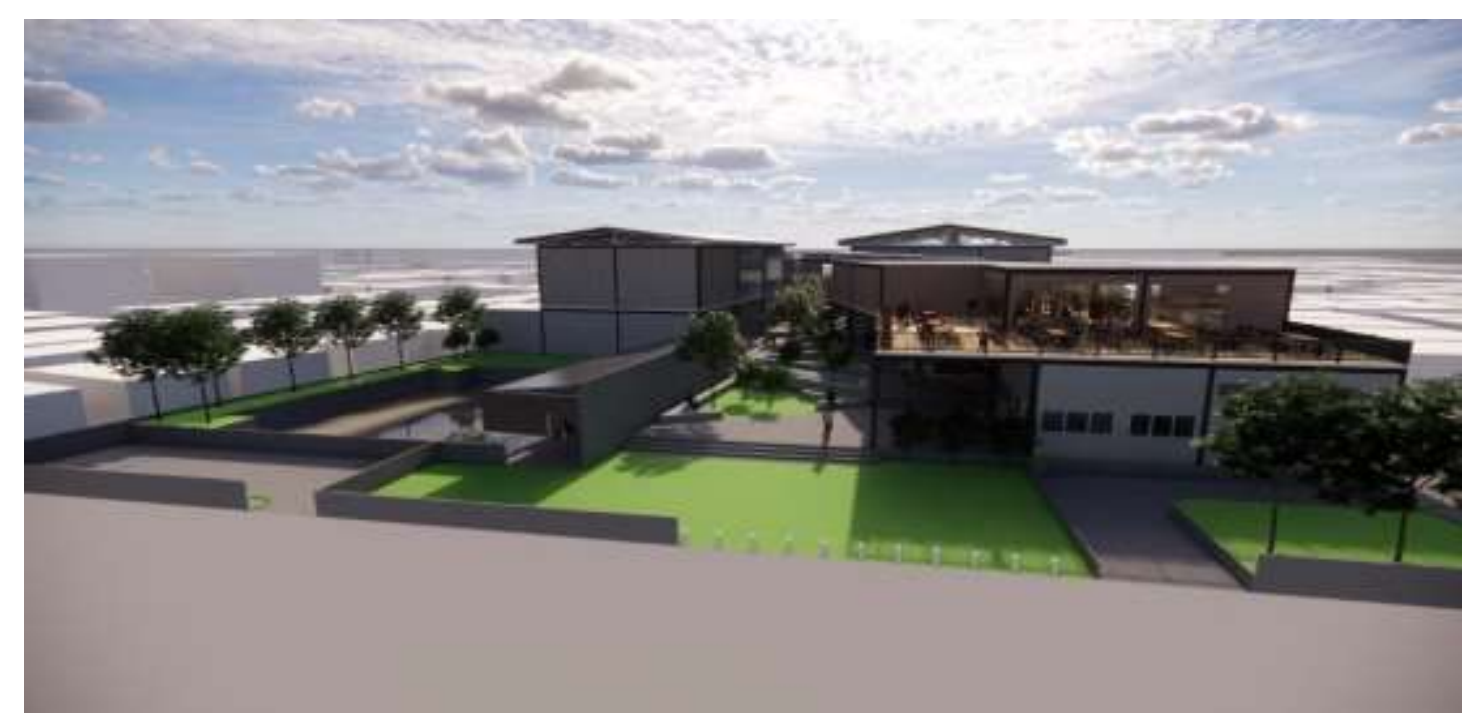

Gambar 12. Gambar perspektif eksterior Sumber: Penulis, 2020 


\section{KESIMPULAN DAN SARAN}

\section{Kesimpulan}

Kampung Nelayan Cilincing yang merupakan pemukiman yang terbentuk secara organik tanpa adanya perencanaan karena urbanisasi yang tidak terkontrol menimbulkan masalah lain dalam tubuh masyarakatnya, dari masalah ekonomi, sosial, sampai ketersediaan fasilitas pendukung pemukiman yang ideal. Balai dan Rekreasi Kampung Nelayan Cilincing merupakan sebuah tempat ketiga yang dihadirkan sebagai reaksi atas keadaan dan masalah-masalah yang terjadi. Dalam bentuk sebuah balai yang dilengkapi dengan fasilitas-fasilitas umum lainnya diharapkan dapat berhasil sebagai titik perkumpulan masyarakat sekitar dan luar dengan tujuan terjadinya interaksi sosial yang positif di tempat tersebut. Interaksi sosial yang positif diharapkan dapat mengurangi, bahkan menyelesaikan konflik sosial yang terjadi dan aktivitas yang timbul membantu perekonomian masyarakat sekitar, sehingga masyarakat Kampung Nelayan Cilincing menjadi komunitas masyarakat yang ideal

\section{REFERENSI}

Ahmadi, A. (2009). Psikologi Sosial. Jakarta: Rineka Cipta

Badan Pengembangan dan Pembinaan Bahasa. (2016). Kamus Besar Bahasa Indonesia. Diakses 25 Juli 2020, dari kbbi.kemdikbud.go.id.

Bali, Muhammad Mushfi El Iq. (2017). Model Interaksi Sosial Dalam Mengelaborasi Keterampilan Sosial. Probolinggo: Universitas Nurul Jadid.

Lindarto, D. \& Harisdani, D. D. (2019). Model Rancangan Desain Revitalisasi Kawasan Niaga. Jakarta: Universitas Muhammadiyah Jakarta

Maki, F. (2017). Open Space: Utopia is not Just a Building. Diakses 13 Januari 2020, dari www.architectural-review.com/essays/open-space-utopia-is-not-a building/10017731.article.

Oldenburg, R. (1997). The Great Good Place. Cambridge: Da Capo Press

Oldenburg, R. (2001). Celebrating the Third Place: Inspiring Stories About the "Great Good Place" at the Heart of Our Communities. New York: Marlowe \& Company. 
